\title{
MODEL TEAMS GAMES TOURNAMENT: Suatu Analisis Hasil Implementasi dalam Pembelajaran Pendidikan Agama Islam
}

\author{
Mokh. Iman Firmansyah, \\ Yusuf Ali Tantowi, dan Gina Ratnanisa Fawziah \\ Universitas Pendidikan Indonesia, Bandung \\ *E-mail: mokbiman.712@upi.edu
}

\begin{abstract}
The effectiveness of a model can be seen from an indication of the increased quality of the process and learning outcomes. High or low student learning activities have an influence on the achievement of learning objectives that have been set. The preliminary study results showed the phenomenon of the low learning activities of class VII F students in PAI learning, especially in doing assignments and discussing in groups which of course must be solved immediately. Through the descriptive method with the CAR model, it is known that the alternative solution is to apply the teams games tournament (TGT) model. After going through two cycles of action and each cycle goes through the stages of planning, implementation, observation, and evaluation, showing the results that the application of the TGT learning model has become a trigger in increasing student learning activities in PAI learning. Students interested in getting involved in games and tournaments after previously taking steps in presenting and working with teams.
\end{abstract}

Keywords: Teams Games Tournament Model, Learning Activities, Learning of PAI

Abstrak. Efektivitas suatu model terlibat dari indikasi meningkatnya kualitas proses dan hasil pembelajaran. Tinggi atau rendahnya aktivitas belajar siswa memiliki pengarub terhadap tercapaianya tujuan pembelajaran yang telab ditetapkan. Hasil studi pendabuluan diketabui fenomena rendahnya aktivitas belajar siswa kelas VII F dalam pembelajaran PAI, terutama dalam mengerjakan tugas dan berdiskusi dalam kelompok yang tentunya harus segera dipecabkan. Melalui metode deskriptif dengan model PTK, diketahui bahwa alternatif pemecahannya adalah dengan menerapkan model teams games tournament (TGT). Setelah melalui dua tindakan siklus dan setiap siklusnya menempub tahap perencanaan, pelaksanaan, observasi, dan evaluasi, menunjukkan hasil bahwa penerapan model pembelajaran TGT telah menjadi pemantik dalam meningkatkan aktivitas belajar siswa dalam pembelajaran PAI. Siswa mempunyai ketertarikan untuk terlibat dalam games dan tournament setelah sebelumnya menempuh langkah penyajian dan berkerja bersama tim.

Kata Kunci: Model Teams Games Tournament, Aktivitas Belajar, Pembelajaran PAI 


\section{PENDAHULUAN}

Penerapan suatu model pembelajaran dikatakan berhasil apabila efektif mencapai tujuan yang telah ditetapkan, baik secara proses maupun hasil. Keberhasilan secara proses ditandai dengan kemampuan membangkitkan etos dan motivasi anak didik dalam belajar (Marno \&Idris, 2012: 20). Adapun keberhasilan secara hasil ditandai dengan meningkatnya pemahaman yang lebih baik terhadap materi yang dipelajari.

Tuntutan kreativitas guru dalam menerapkan model pembelajaran sebagaimana di atas dapat dipahami dalam rangka menghindari terjadinya interaksi belajar yang pasif yang mana hanya guru yang mendominasi kelas dalam pembelajaran (Duatepe-Paksu dan Ubuz, 2009). Pun harus menghindari aktivitas belajar yang membosankan sehingga berdampak pada rendahnya hasil belajar siswa (Honeycutt \& Pierce, 2007).

Timbulnya kejenuhan, kurang antusias, dan pasifnya siswa dalam proses pembelajaran tak dapat terelakan manakala model yang diterapkan tidak tepat. Kondisi demikian sebagaimana pula terjadi pada siswa kelas VII SMP Negeri 40 Bandung pada semester Ganjil tahun ajaran 2018/2019, dimana berdasarkan hasil identifikasi menunjukkan fenomena rendahnya aktivitas dalam belajar.

Berkaitan dengan gap di atas, maka telah banyak para ahli pembelajaran yang berusaha untuk menemukan suatu model pembelajaran yang inovatif. Inovatif di sini bermakna baru, dan dihasilkan berdasar dan bersandar pada suatu kerangka teori belajar tertentu.

Model pembelajaran adalah pola umum perilaku pembelajaran untuk mencapai tujuan pembelajaran (Joyce, et.al., 2009). Model disebut pula kerangka konseptual yang melukiskan prosedur yang sistematis dan terencana serta bertahap untuk mencapai tujuan pembelajaran (Winataputra, 2005: 3; Setiani dan Priansa, 2015: 150; Tayeb, 2017: 48). Simpulannya bahwa model pembelajaran adalah kerangka atau bingkai sistematis dan terorganisir yang menggambarkan tahapan pembelajaran dari awal sampai akhir untuk mencapai tujuan yang telah ditetapkan.

Joyce, et.al. (2009) mengetengahkan key ideas karakteristik suatu model pembelajaran. Kesatu, Sintaks (syntax) yakni langkah-langkah, fase-fase, atau urutan kegiatan pembelajaran. Untuk mempermudah pemahaman karakteristik kesatu ini, dibuat dalam tabel berikut:

Tabel 1. Model Sintaks

\begin{tabular}{|c|c|c|c|}
\hline Model & Fase I & Fase II & Fase III \\
\hline A & $\begin{array}{l}\text { Penya- } \\
\text { jian } \\
\text { kon- } \\
\text { sep }\end{array}$ & $\begin{array}{l}\text { Penya- } \\
\text { jian data }\end{array}$ & $\begin{array}{l}\text { Meghu- } \\
\text { bungkan } \\
\text { data } \\
\text { dengan } \\
\text { konsep- } \\
\text { kosep }\end{array}$ \\
\hline B & $\begin{array}{l}\text { Penya- } \\
\text { jian } \\
\text { data }\end{array}$ & $\begin{array}{l}\text { Meng- } \\
\text { adakan } \\
\text { katego- } \\
\text { risasi } \\
\text { oleh } \\
\text { pembe- } \\
\text { lajar }\end{array}$ & $\begin{array}{l}\text { Identifi- } \\
\text { kasi } \\
\text { konsep }\end{array}$ \\
\hline
\end{tabular}

Sumber: Joyce, et.al. (2009)

Kedua; Prinsip reaksi (principle of reaction) yaitu reaksi pembelajar atas aktvitas-aktivitas. Dalam contoh model B (tabel 1), mungkin selama fase II (dua) pembelajar memberi contoh cara meyusun konsep, dan memberanikan pembelajar membandingkan konsepkonsep mereka.

Ketiga, Sistem sosial (sosial system) yang mencakup tiga pengertian utama yakni deskripsi macam-macam peranan

TARBAWY: Indonesian Journal of Islamic Education - Vol. 6 No. 2 (2019) | 105 
pembelajar dan pengajar, deskripsi hubungan hierarkis atau otoritas pembelajar dan pengajar, dan deskripsi macam-macam kaidah untuk mendorong pembelajar.

Keempat, Sistem pendukung (support system), yakni kondisi yang dibutuhkan oleh suatu model. Dukungan apa yang dibutuhkan oleh suatu model agar tercipta lingkungan khusus. Dalam hubungan ini, sistem pendukung itu berupa kemampuan atau keterampilan dan fasilitas-fasilitas teknis.

Salah satu model yang berhasil ditemukan dan dikembangkan adalah bentuk model kooperatif. Menurut Isjoni (2014: 15) model kooperatif adalah suatu bentuk model dimana para siswa dalam aktivitas belajarnya dilakukan secara berkelompok, bekerjasama dalam suatu tim. Tujuan bentuk model ini sedikitnya mengarah pada tiga hal yakni pengkuan adanya keragaman, pengembangan keterampilan sosial, dan hasil belajar (Setiani dan Priansa, 2015: 244-245).

Langkah atau sintaks dari model pembelajaran kooperatif menurut Agus Suprijono terdiri atas enam fase berikut:

Tabel 2. Sintaks Model Pembelajaran Kooperatif

\begin{tabular}{ll}
\hline \multicolumn{1}{c}{ Fase-Fase } & \multicolumn{1}{c}{ Perilaku Guru } \\
\hline Fase 1: Present & Mejelaskan tujuan \\
goals and set & pembelajaran dan \\
Meyampaikan & mempersiapkan \\
tujuan dan & peserta didik siap \\
mempersiapkan & belajar. \\
peserta didik & \\
\hline Fase 2: Present & Mempresentasikan \\
information & informasi kepada \\
Meyajikan & peserta didik secara \\
informasi & verbal \\
Fase 3: Organize & Memberikan \\
student into learning & penjelasan kepada \\
teams & peserta didik \\
Mengorganisir & tentang cara \\
\hline
\end{tabular}

peserta didik ke pembentukan tim dalam tim-tim belajar dan belajar membantu kelompok melakukan transisi yang efisien

\begin{tabular}{ll}
\hline $\begin{array}{l}\text { Fase 4: Assist } \\
\text { team work and }\end{array}$ & $\begin{array}{l}\text { Membantu tim-tim } \\
\text { study }\end{array}$ \\
$\begin{array}{l}\text { Membantu kerja } \\
\text { tim dan belajar }\end{array}$ & $\begin{array}{l}\text { mengerta didik } \\
\text { tugasnya. }\end{array}$ \\
\hline Fase 5: Test on the & Menguji \\
materials & pengetahuan \\
Megevaluasi & peserta didik \\
& menegnai berbagai \\
& materi \\
& pembelajaran atau \\
& kelompok- \\
& kelompok \\
& mempresentasikan \\
& hasil kerjanya.
\end{tabular}

\begin{tabular}{ll}
\hline Fase 6: Provide & Mempersiapkan \\
recognition & cara untuk megakui \\
Memberikan & usaha dan prestasi \\
pegakuan atau & individu maupun \\
penghargaan & kelompok.
\end{tabular}

Sumber: Suprijono (2015: 76)

Teams games tournament (TGT) merupakan tipe model yang berhasil dikembangkan oleh David The Vries dan Keath Edward di tahun 1995. Pada model ini siswa memainkan permainan dengan anggota tim lain untuk memperoleh tambahan poin untuk skor tim mereka (Al-Tabany, 2015: 131).

Menurut Slavin, model pembelajaran kooperatif tipe TGT menempuh lima langkah tahapan (sintaks), yakni penyajian (class presentation), belajar dalam kelompok (teams), permainan (games), pertandingan (tournament), dan penghargaan (team recognition). Model pembelajaran TGT tidak hanya melatih menguasai pelajaran, juga membuat siswa antusias dalam 
mengikuti pembelajaran serta melatih bagaimana cara bekerjasama dalam kelompok (Rusman, 2012: 225).

\section{METODE PENELITIAN}

Sintaks model TGT sebagaimana dikemukakan Slavin, dipraktikkan dalam suatu rangkaian penelitian deskriptif bentuk tindakan kelas (classroom action research) di kelas VII F SMP Negeri 40 Bandung pada semester ganjil tahun ajaran 2018-2019 dengan subjek sebanyak 31 orang. Pertimbangan penerapan model PTK merujuk pendapat Dave Ebbutt, bahwa model penelitian ini merupakan studi sistematis yang dilakukan dalam bentuk tindakan dan tahapan yang jelas sampai menghasilkan refleksi (Hopkins, 2011: 87).

Setiap tindakan dilakukan secara bersiklus dimana setiap siklusnya menempuh empat tahap. Keempat tahap dalam siklusnya diuraikan sebagai berikut: Pertama, tahap perencanaan yakni tahap yang di dalamnya disusun RPP, instrumen observasi pembelajaran dan skala sikap untuk mengetahui respon siswa pasca penerapan model TGT, dan media pembelajaran. Kedua, tahap pelaksanaan yakni implementasi tindakan dengan menerapkan model TGT sesuai perencanaan yang telah disusun. Ketiga, tahap observasi yakni kegiatan pengamatan yang dilaksanakan bersamaan dengan proses pembelajaran baik terhadap aktivitas belajar siswa dengan menggunakan instrumen yang telah disusun. Keempat, tahap refleksi yakni tahap evaluasi yang dilakukan observer dan kemudian didiskusikan hasilnya bersama dengan peneliti (Susilo, 2007: 23; Arikunto, et.al:: 2009: 18; Kunandar, 2010: 71).
Berkaitan dengan penggalian data, maka disusun instrumen khusus untuk memperoleh deskripsi aktivitas belajar siswa. Hasil dari instrumen tersebut kemudian dikoversikan ke dalam bentuk angka dengan mengacu pada penskoran sebagaimana tabel 3. berikut:

Tabel 3. Penskoran Hasil Observasi Aktfitas Belajar Siswa

\begin{tabular}{lc}
\hline \multicolumn{1}{c}{ Kriteria } & Skor \\
\hline ST (Sangat Tinggi) & 5 \\
T (Tinggi) & 4 \\
CT (Cukup Tinggi) & 3 \\
KT (Kurang Tinggi) & 2 \\
TT (Tidak Tinggi) & 1 \\
\hline
\end{tabular}

Sumber: Sugiyono (2013: 136)

Hasil angka pada tabel 3. Kemudian dikonversikan kepada katagori kualitatif sebagaimana pada tabel berikut:

Tabel 4. Kriteria Katagori Aktivitas Belajar Siswa

\begin{tabular}{cc}
\hline Presentase & Kategori \\
\hline $80 \%-100 \%$ & Sangat Tinggi \\
$60 \%-79 \%$ & Tinggi \\
$40 \%-59 \%$ & Cukup \\
$20 \%-39 \%$ & Rendah \\
$0 \%-19 \%$ & Sangat Rendah \\
\hline
\end{tabular}

Selain mengamati aktivitas belajar siswa, pada penelitian ini juga digali data berkaitan dengan respon siswa pasca penerapan model TGT. Untuk menggali data tentang respon siswa tersebut, maka digunakan instrumen skala sikap dengan penskoran sebagaiman pada tabel 4 . berikut:

Tabel 4. Penskeroran Hasil Observasi Skala Sikap

\begin{tabular}{lc}
\hline \multicolumn{1}{c}{ Kriteria } & Skor \\
\hline ST (Sangat Tinggi) & 5 \\
T (Tinggi) & 4 \\
CT (Cukup Tinggi) & 3 \\
KT (Kurang Tinggi) & 2 \\
\hline
\end{tabular}




\begin{tabular}{ll}
\hline TT (Tidak Tinggi) & 1 \\
\hline Sumber: Sugiyono (2013: 136) &
\end{tabular}

Data angka yang dihasilkan setiap variabelnya, kemudian diolah ke dalam bentuk persentase dengan rumus dari Arikunto (1996, hal. 244):

\section{Persentase $=\underline{\text { S.obsrv. } \times 100 \%}$ Skor yang diharapkan}

Rangkaian akhir analisis data dalam tindakan kelas ini adalah mengonfirmasi respon positif atau sebaliknya pasca penerapan model TGT. Cara yang digunakan dengan menggunakan tabel interpretasi sebagai berikut:

Tabel 5. Interpretasi Respon terbadap Penerapan Model TGT

\begin{tabular}{ll}
\hline Presentase & Kategori \\
\hline $81 \%-100 \%$ & $\begin{array}{l}\text { Sangat kuat/Sangat } \\
\text { Positif }\end{array}$ \\
$61 \%-80 \%$ & Kuat/Positif \\
$41 \%-60 \%$ & Cukup/Cukup \\
$21 \%-40 \%$ & Lemah/Kurang \\
$0 \%-20 \%$ & Sangat \\
& lemah/Tidak \\
& Berdampak \\
\hline
\end{tabular}

(Riduwan \& Akdon, 2013)

\section{HASIL PENELITIAN DAN PEMBAHASAN}

Tindakan siklus I dilaksanakan sebanyak dua kali pertemuan dengan materi yang dibahas tentang Shalat Berjamaah, dimana penekanannya pada mengulang bacaan salat berjamaah serta gerakannya. Konten bacaan shalat dan gerakannya merupakan aspek yang di games tournamentkan.

Hasil observasi terhadap kegiatan peneliti pada siklus I menunjukkan bahwa aktivitas peneliti dalam beberapa indikator masih menunjukkan kinerja belum optimal. Ketidakoptimalan kinerja tersebut berkaitan dengan aspek variatif media menyajikan materi pelajaran, kejelasan aturan main model teams games torunament perlu penekanan kembali pada tindakan berikutnya. Ketidakmengertian siswa atas aturan main pembelajaran dengan model TGT ini terutama terlihat pada siklus I pertemuan kesatu. Aspek lain yang harus diperbaiki pada siklus berikutnya adalah pentingnya setiap siswa harus diberikan materi kerja dalam kelompok maisng-masing yang berbeda antara satu dengan yang lainnya. Hal ini dilakukan guna menghindari sikap malas pada seseorang siswa di saat kerja dalam timnya.

Rekomendasi dari hasil refleksi tindakan siklus I tersebut telah diperbaiki oleh peneliti pada siklus II. Pada siklus II materi yang dibahas adalah "Dengan Ilmu Pengetahuan Semua Menjadi Lebih Mudah" dengan subab bahasannya yaitu membaca Q.S Ar-Rahman: 33 Q.S AlMujadalah: 11, menerapkan ilmu tajwid Al "Syamsiah" dan Al "Qomariah", arti mufradat dan terjemahan, kandungan Q.S Ar-Rahman: 33 dan Q.S AlMujadalah: 11, serta perilaku orang cinta dengan ilmu pengetahuan.

Hasil observasi pada siklus II yakni terhadap kinerja peneliti menunjukan banyak perubahan. Penjelasan yang rinci dan terarah tentang aturan main model TGT ini telah mampu mengarahkan perilaku belajar siswa setiap tahapannya. Kemudian pula peneliti telah mampu memvariasikan media untuk menyuguhkan materi pada siklus II. Kombinasi media visual dan handmade telah mestimulasi siswa untuk lebih antusias dalam menyimak. Antusias dan semangat siswa dalam mengikuti games dengan bantuan media 'kartu hukum bacaan' dimana setiap kelompok harus menganalisis hukum bacaan sesuai yang terdapat di dalam kartu yang dipilihnya.

Pertemuan kedua pun siswa mulai terlihat terbiasa dengan mengulang dan membiasakan membaca ayat Alquran yang sedang di pelajari. Pertemuan kedua

TARBAWY: Indonesian Journal of Islamic Education - Vol. 6 No. 2 (2019) $\mid \mathbf{1 0 8}$ 
ini peneliti mengadakan game menyusun kedua ayat yang harus di selesaikan selama 10 menit tanpa melihat buku.

Intruksi kerja dalam kelompok (tim) yang dibuat oleh peneliti dengan masingmasing siswa berbeda garapan kerja, telah menjadikan setiap individu siswa aktif bekerjasama dalam tim. Semua siswa terlibat aktif dalam kerja, suasana kelas terlihat semakin hidup dan bersemangat ketika peneliti menyampaikan materi huruf-huruf dari hukum bacaan alif lam dengan mengulang satu per satu huruf. Kegiatan pembelajaran PAI pada siklus II semakin membuat siswa antusias terutama dalam membahas dalam materi huruf-huruf alim lam dan arti mufrodat atau arti kata per kata. Games dan torunament berhasil dalam memotivasi siswa dalam berkompetisi dengan tim lain.

Pada saat tournament dimulai, terjadi terdapat perbedaan antara tindakan siklus I dengan siklus II. Pada siklus I, hampir seluruh tim lupa dengan aturan bahwa setiap tim boleh menambahkan atau menyempurnakan jawaban dari kelompok lain yang keliru atau perlu tambahan. Akan tetapi pada siklus II, peneliti berhasil dalam mengingatkan poin itu kepada kelas, sehingga nampak sekali ketika satu tim sedang menjawab, maka tim lain sangat memperhatikan, dan jika terdapat jawaban keliru, maka tim yang lain segera meminta kesempatan untuk menambahkan dan memperbaikinya.

Sebagai rangkaian akhir dari penerapan model TGT ini, peneliti melakukan internalisasi nilai tentang pentingnya bejerjasama dalam tim. Pengaitan materi pentingnya bekerjasama dengan ilustrasi "banyak tangan untuk menjadi sebuah kemeja" sangat menarik perhatian siswa. Pemaknaan sabar dan menerima setiap kenyataan, merupakan internalisasi kedua yang diberikan.
Setelah menempuh dua siklus tindakan (tindakan siklus I dilaksanakan 3 dan 10 Oktober 2018; tindakan siklus II dilaksanakan 31 Oktober dan 7 November 2018), diperoleh hasil sebagai berikut:

Tabel 5. Hasil Observasi Penilaian Aktivitas Belajar Siswa

\begin{tabular}{|c|c|c|c|c|c|}
\hline \multirow{3}{*}{$\mathbf{N}$} & \multirow{3}{*}{ Aktivitas } & \multicolumn{4}{|c|}{ Penilaian } \\
\hline & & \multicolumn{2}{|c|}{ Siklus I } & \multicolumn{2}{|c|}{ Siklus II } \\
\hline & & 1 & 2 & 1 & 2 \\
\hline \multicolumn{6}{|c|}{$\begin{array}{lll}\text { Aktivitas } & \text { pada } & \text { Tahap }\end{array}$} \\
\hline \multicolumn{6}{|c|}{ Penyajian } \\
\hline 1 & $\begin{array}{l}\text { Memperhatikan guru } \\
\text { menyampaikan materi } \\
\text { PAI di kelas }\end{array}$ & 3 & 4 & 5 & 5 \\
\hline 2 & $\begin{array}{l}\text { Bertanya tentang materi } \\
\text { PAI yang belum jelas }\end{array}$ & 3 & 3 & 3 & 4 \\
\hline 3 & $\begin{array}{l}\text { Menjawab pertanyaan } \\
\text { yang diberikan oleh guru }\end{array}$ & 3 & 3 & 4 & 4 \\
\hline \multicolumn{6}{|c|}{$\begin{array}{l}\text { Aktivitas Belajar dalam } \\
\text { Kelompok }\end{array}$} \\
\hline 4 & $\begin{array}{l}\text { Bekerja dan bekerjasama } \\
\text { dalam kelompok }\end{array}$ & 2 & 2 & 3 & 4 \\
\hline \multicolumn{6}{|c|}{ Aktivitas dalam Games } \\
\hline 5 & $\begin{array}{l}\text { Terlibat dan antusias } \\
\text { dalam bermain games }\end{array}$ & 2 & 3 & 4 & 4 \\
\hline \multicolumn{6}{|c|}{ Aktivitas dalam Toumament } \\
\hline 6 & $\begin{array}{ll}\text { Setiap } & \text { kelompok } \\
\text { berlomba } & \text { menjawab } \\
\text { pertanyaan } & \end{array}$ & 3 & 4 & 4 & 5 \\
\hline 7 & $\begin{array}{l}\text { Berusaha } \\
\text { menyempurnakan } \\
\text { jawaban kelompok lain } \\
\text { yang belum keliru atau } \\
\text { belum lengkap }\end{array}$ & 1 & 2 & 4 & 5 \\
\hline \multicolumn{6}{|c|}{ Aktivitas Recognition } \\
\hline 8 & $\begin{array}{lr}\text { Berbangga atas } & \text { hasil } \\
\text { kelompok } & \text { yang } \\
\text { diperoleh } & \text { setelah } \\
\text { mengikuti tournament }\end{array}$ & 2 & 3 & 4 & 5 \\
\hline 9 & $\begin{array}{l}\text { Menerima atas } \\
\text { penghargaan yang } \\
\text { diperoleh kelompoknya }\end{array}$ & 1 & 3 & 4 & 5 \\
\hline
\end{tabular}

\begin{tabular}{|c|c|c|c|c|c|}
\hline \multicolumn{6}{|c|}{ Value Nurturant Effect } \\
\hline 10 & $\begin{array}{l}\text { Mampu bekerjasama } \\
\text { dalam tim kelompoknya }\end{array}$ & 2 & 3 & 4 & 4 \\
\hline 11 & $\begin{array}{l}\text { Berlapang dada saat } \\
\text { pendapat tidak dapat } \\
\text { diterima dalam diskusi }\end{array}$ & 2 & 3 & 4 & 4 \\
\hline \multicolumn{2}{|c|}{ Jumlah Skor } & $\begin{array}{l}2 \\
4\end{array}$ & 33 & 43 & 49 \\
\hline \multirow{2}{*}{\multicolumn{2}{|c|}{ Jumlah Maksimal }} & $\begin{array}{l}5 \\
5\end{array}$ & 55 & 55 & 55 \\
\hline & & 4 & 60 & 78 & 89 \\
\hline \multicolumn{2}{|c|}{ Persentase } & $\begin{array}{l}4 \\
\%\end{array}$ & $\%$ & $\%$ & $\%$ \\
\hline \multicolumn{2}{|c|}{ Persentase Akhir } & \multicolumn{2}{|c|}{$52 \%$} & \multicolumn{2}{|c|}{$84 \%$} \\
\hline
\end{tabular}

Sumber: Hasil Observasi Aktivitas Belajar, 2018

Data pada tabel 5. tersebut dibuat dalam grafik batang sebagaimana di bawah ini: 


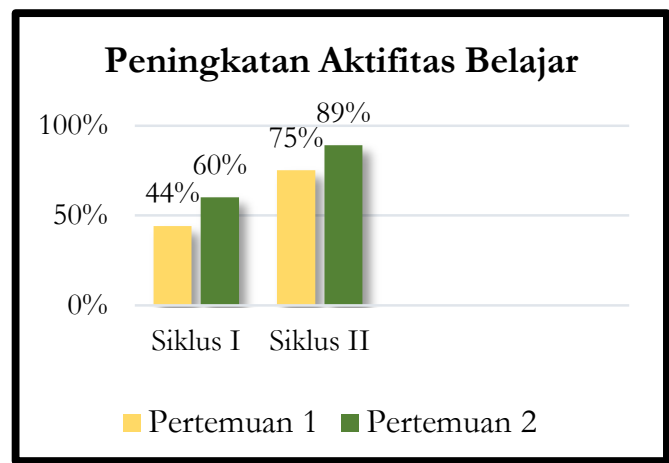

Gambar 1. Peningkatan Aktifitas Belajar Pasca Penerapan Model TGT dalam Pembelajaran PAI

Dari tabel 5, menunjukkan bahwa aktivitas belajar siswa kelas VII F mengalami peningkatan signifikan dari mulai tindakan siklus I sampai pada tindakan siklus II. Aktivitas yang kurang pada siklus I dengan nilai kurang aktif adalah bekerja dan bekerjasama dalam kelompok. Aktivitas bekerja dalam kelompok masih didominasi siswa yang sebelumnya pun suka mendominasi. Di dalam bekerjasama pun siswa cenderung lebih banyak diam.

Keadaan tersebut berubah pada tindakan siklus II ke arah aktivitas yang tinggi. Aktivitas belajar yang paling menonjol adalah antusias dalam memperhatikan guru pada saat menyampaikan materi di kelas terutama mengenai penjelasan games dan torunament. Aspek lainnya yang meningkat adalah bekerjasama dalam kelompok dimana pada siklus II mengalami perubahan meskipun tidak mencapai nilai sangat baik. Siswa menunjukkan keaktifan dalam bekerja dan bekerjasama dalam kelompoknya. Dominasi pada seseorang siswa tertentu (maksudnya yang aktif) menjadi tidak ada lagi, melebur menjadi kerja kerjasama tim yang aktif. Proses bimbingan dan bantuan semangat dari peneliti menjadi variabel lain yang meningkatkan aktivitas siswa dalam indikator ini.

Indikator lainnya yang menjadi sorotan observer adalah siswa aktif mendengarkan dan berusaha melengkapi dan menyempurnakan jawaban kelompok lain yang keliru atau belum lengkap pada sesi tournament. Pada siklus I, siswa cenderung terjebak dengan jawaban kelompoknya saja, sehingga mereka lupa bahwa ada kesempatan bagi kelompknya untuk memberikan tambahan jawaban atau memperbaiki jawaban kelompok lain.

Berlapang dada saat pendapat tidak dapat diterima dalam berdiskusi di kelompok masing-masing merupakan nilai lain yang digali dalam penelitian ini. Pada siklus I, beberapa siswa belum memperlihatkan rasa menghargai sehingga sulit menerima pendapat dari tim lain. Peran peneliti sangat membantu sehingga pada siklus II, siswa mulai menunjukkan sikap berlapang dada dan menghargai pendapat kelompok lain.

Secara keseluruhan, aktivitas belajar siswa kelas VII F setelah melewati dua siklus tindakan dengan menerapkan model TGT dalam pembelajaran PAI menunjukkan aktivitas sangat tinggi. Terlihat dari peningkatan persentase dari $52 \%$ pada siklus I menjadi $84 \%$ pada siklus II. Artinya, aktivitas belajar siswa meningkat dari aktivitas cukup menjadi aktivitas sangat tinggi.

Selanjutnya digali data mengenai respon siswa pasca penerapan model TGT, untuk mengetahui beberapa dampaknya sebagaimana tabel 6. Berikut ini:

Tabel 6. Respon Siswa Pasca Penerapan Model TGT

\begin{tabular}{|c|c|c|c|c|}
\hline No & $\begin{array}{l}\text { Indikator } \\
\text { Sikap }\end{array}$ & $\begin{array}{c}\text { Ha- } \\
\text { sil }\end{array}$ & $\%$ & $\begin{array}{c}\text { Kata- } \\
\text { gori }\end{array}$ \\
\hline 1. & $\begin{array}{l}\text { Saya menjadi } \\
\text { semangat } \\
\text { mengikuti } \\
\text { pembelajaran } \\
\text { dengan } \\
\text { menggunakan } \\
\text { model } \\
\text { pembelajaran } \\
\text { Teams Games } \\
\text { Tournament }\end{array}$ & 125 & $81 \%$ & $\begin{array}{l}\text { Sangat } \\
\text { Positif }\end{array}$ \\
\hline 2. & $\begin{array}{ll}\begin{array}{l}\text { Saya } \\
\text { mudah }\end{array} & \text { lebih } \\
\end{array}$ & 127 & $82 \%$ & $\begin{array}{l}\text { Sangat } \\
\text { Positif }\end{array}$ \\
\hline
\end{tabular}




\begin{tabular}{|c|c|c|c|c|}
\hline & $\begin{array}{l}\text { memahami } \\
\text { materi pelajaran } \\
\text { dengan Model } \\
\text { pembelajaran } \\
\text { Teams Games } \\
\text { Tournament }\end{array}$ & & & \\
\hline 3. & $\begin{array}{l}\text { Saya menjadi } \\
\text { lebih mudah } \\
\text { mengerjakan } \\
\text { tugas yang } \\
\text { diberikan oleh } \\
\text { guru dengan } \\
\text { adanya model } \\
\text { pembelajaran } \\
\text { Teams Games } \\
\text { Tournament }\end{array}$ & 120 & $77 \%$ & Positif \\
\hline 4. & $\begin{array}{l}\text { Saya menjadi } \\
\text { lebih aktif ketika } \\
\text { sedang } \\
\text { berdiskusi secara } \\
\text { berkelompok } \\
\text { dengan model } \\
\text { pembelajaran } \\
\text { Teams Games } \\
\text { Tournament. }\end{array}$ & 116 & $75 \%$ & Positif \\
\hline 5. & $\begin{array}{l}\text { Saya dapat } \\
\text { menumbuhkan } \\
\text { sikap positif } \\
\text { seperti } \\
\text { kerjasama, } \\
\text { toleransi, serta } \\
\text { bisa menerima } \\
\text { pendapat orang } \\
\text { setelah belajar } \\
\text { dengan model } \\
\text { pembelajaran } \\
\text { Teams Games } \\
\text { Tournament }\end{array}$ & 121 & $78 \%$ & Positif \\
\hline
\end{tabular}

Dari tabel 6. dapat dianalisis bahwa penerapan model TGT dalam pembelajaran PAI direspon siswa sangat positif dan positif. Indikator semangat mengikuti pembelajaran PAI dengan model TGT sehingga menjadi membantu memudahkan dalam memahami materi direspon sangat positif oleh siswa. Adapun untuk tiga indikaktor lainnya bahwa model TGT membantu siswa dalam mempermudah mengerjakan tugas karena berkelompok, menjadi aktif dalam berdiskusi, serta dapat menumbuhkan sikap positif dalam teams, games, dan tournament direspon positif oleh siswa.

Pemberian penguatan pada sintaks terakhir penerapan model ini telah meningkatkan antusias siswa pada saat games dan torunament. Mengacu kepada pendapat Berliner ternyata penguatan ini merupakan stimulus yang direspon positif oleh siswa. Dalam teori belajar behavioristik pemberian penguatan yang positif dan tepat dapat meningkatkan respon yang positif (Slavin, 2000).

Dasar dari penerapan model TGT dalam penelitian ini adalah rendahnya aktivitas belajar yang disebabkan kesulitan-kesulitan yang dialami siswa dalam pembelajaran PAI. Salah satu kesulitannya adalah dalam membaca Alquran. Hal ini menjadi pemicu tidak aktifnya siswa dalam pembelajaran PAI, mengingat mayoritas konten PAI memiliki dasar dalil. Kesulitan belajar adalah suatu keadaan dimana siswa tidak dapat belajar sebagaimana mestinya. Faktor penyebabnya tidak selalu oleh faktor intelengensi, akan tetapi juga dapat disebabkan oleh faktor non intelengensi, adanya gangguan (internal maupun eksternal). Imbasnya dari faktor-faktor tersebut membuat siswa menjadi tidak berkembang sesuai dengan kapasitasnya (Ahmadi dan Supriyono, 2013: 77). Hamalik (2005: 117) menganalisis bahwa faktor kurangnya minat dan antusias belajar dalam menjadi penyebab rendahnya aktivitas belajar.

Penerapan model pembelajaran TGT telah menjadi pemantik dalam meningkatkan aktivitas belajar siswa dalam pembelajaran PAI. Siswa mempunyai ketertarikan untuk terlibat dalam games dan tournament setelah sebelumnya menempuh langkah penyajian dan berkerja bersama tim. Penelitian ini juga telah menunjukkan bahwa motivasi dari guru sangatlah penting. Motivasi merupakan proses yang menstimulasi perilaku atau mengerakkan untuk bertindak. Motivasilah yang membuat bertindak dengan cara tertentu. Literatur penelitian tentang kelas dan motivasi cukup ekstensif dan mempresentasikan ilmu 
pengetahuan dari banyak bidang bahwa perilaku guru memengaruhi motivasi dan kehidupan, dan bagaimana siswa-siswa itu sendiri dapat saling memengaruhi teman-teman sekelas dan gurunya (Arends, 2007: $143 \&$ 153).

\section{KESIMPULAN}

Penerapan model TGT dalam penelitian ini berjalan sesuai perencanaan yang disusun. Hal ini artinya bahwa penerapan model TGT harus dirancang dalam suatu perencanaan yang matang.

Model pembelajaran TGT dalam penelitian tindakan kelas ini telah mampu meningkatkan kualitas pembelajaran PAI. Kualitas tersebut diwujudkan dengan meningkatnya aktivitas belajar siswa. Indikasinya adalah siswa menjadi antusias dalam menyimak pematerian dari guru dan berusaha memahami intruksi kerja dari model ini. Pada sesi kelompok, siswa juga mampu bekerja dan bekerjasama dalam tim berdasarkan tanggung jawabnya masingmasing. Siswa dilatih memiliki sikap kompetitif secara terbuka berdasarkan potensi kelompok masing-masing. Selain itu, siswa dilatih pula memiliki sensitivitas sosial dengan bertanggungjawab atas tugas, menghargai perbedaan, dan termasuk sikap menerima atas perbedaan hasil.

Dalam proses pembelajaran, pada dimensi sosial, siswa dilatih untuk menerima perbedaan dalam timnya. Mengerjakan tugas yang diberikan berbeda kepada setiap individu. Menyemangati kepada masing-masing anggota tim dalam sesi torunament, serta menerima hasil apapun yang diperoleh timnya tersebut.

\section{REFERENSI}

Ahmadi dan Supriyono. (2013). Psikologi Belajar. Jakarta: PT. Rineka Cipta.

Arends, R. I. (2007). Learning To Teach (Belajar untuk Mengajar). (Edisi Ketujuh/Jilid I). (H. P. Soetjipto, \& S. Mulyantini Soetjipto, Trans.) Yogyakarta: Pustaka Pelajar.

Arikunto, S. (2006). Prosedur Penelitian Suatu Pendekatan Praktik. Jakarta: Asdi Mahastya.

Arikunto, S. et.al. (2009). Penelitian Tindakan Kelas. Jakarta: PT Bumi Aksara.

Al-Tabany, T. I. (2015). Mendesain Model Pembelajaran Inovatif, Progresif, dan Kontekstual. Jakarta: PT Kharisma Putra Utama.

Duatepe-Paksu, A., \& Ubuz, B. (2009). Efek Instruksi Geometri Berbasis Drama Pada Prestasi Siswa, Sikap, dan Tingkat Berpikir. Jurnal Penelitian Pendidikan, 102 (4), 272-288.

Hamalik. (2005) Kurikulum dan Pembelajaran. Jakarta: Bumi Aksara.

Honeycutt, B., \& Pierce, B. (2007). Menggambarkan Probabilitas dalam Genetika dengan Pembelajaran Langsung: Membuat Matematika Menjadi Nyata. The American Biology Teacher, 69 (9), 554-561.

Hopkins, d. (2011). Pandua Guru: Penelitian Tindakan Kelas. Terjemahan oleh Achmad Fawaid. Yogjakarta: Pustaka Pelajar.

Isjoni. (2014). Cooperative Learning: Menegmbangkan: Kemampuan Belajar Berkelompok. Bandung: Alfabeta.

Joyce, et.al. (2009). Models of Teaching. Yogjakarta: Pustaka Pelajar.

Kunandar. (2010). Langkah Mudah Penelitian Tindakan Kelas sebagai Pengembangan Profesi Guru. Jakarta: PT Raja Grafindo Persada. 
Marno \& M.Idris. (2012). Strategi \& Metode Pengajaran: Menciptakan Keterampilan Mengajar yang Efektif dan Edukatif. Yogjakarta: Ar-Ruzz Media.

Riduwan, \& Akdon. (2013). Rumus Dan Data Dalam Analisis Statistika. Bandung: Alfabeta.

Rusman. (2012). Model-Model Pembelajaran. Jakarta: PT. Rajagrafindo Persada.

Setiani, A., \& Juni Priansa, D. (2015). Manajemen Peserta Didik dan Model Pembelajaran: Cerdas, Kreatif, dan Inovatif. Bandung: Alfabeta.

Slavin. (2000). Educational Psychology: Theory and Practice. Six Edition. Boston: Allyn and Bacon.

Sugiyono. (2013). Metodologi Penelitian Kuantitatif. Bandung: Alfabeta.

Suprijono, A. (2015). Cooperative Learning Teori dan Aplikasi PAIKEM. Yogyakarta: Pustaka Pelajar.

Susilo. (2007). Penelitian Tindakan Kelas. Yogyakarta: Pustaka Book Publisher.

Tayeb, T. (2017). Analisis dan Manfaat Model Pembelajaran. Auladuna: Jurnal Pendidikan Dasar Islam, Vol. 4 No. $\quad 2, \quad 48$. doi:https://doi.org/10.24252/aulad una.v4i2a5.2017

Winataputra, U. (2005). Menagjar di Perguruan Tinggi: Model-model Pembelajaran Inovatif. Jakarta: PAUPPAI Universitas Terbuka. 